\title{
Nickel catalyst in coupled plasma-catalytic system for tar removal
}

\author{
Joanna Woroszył-Wojno, Michał Młotek, Bogdan Ulejczyk, Krzysztof Krawczyk
}

Warsaw University of Technology, 3 Noakowskiego Street, 00-664 Warsaw, Poland
"Corresponding authors: e-mail: joanna.woroszyl.dokt@pw.edu.pl

Tar formation is a significant issue during biomass gasification. Catalytic removal of tars with the use of nickel catalyst allows to obtain high conversion rate but coke formation on catalysts surface lead to its deactivation. Toluene decomposition as a tar imitator was studied in gliding discharge plasma-catalytic system with the use of 5\%, $10 \%$ and $15 \%$ by weight $\mathrm{Ni}$ and $\mathrm{NiO}$ catalyst on $\mathrm{Al}_{2} \mathrm{O}_{3}\left(\alpha-\mathrm{Al}_{2} \mathrm{O}_{3}\right)$ and Peshiney $\left(\gamma-\mathrm{Al}_{2} \mathrm{O}_{3}\right)$ carrier in gas composition similar to the gas after biomass pyrolysis. The optimal concentration of nickel was identified to be $10 \%$ by weight on $\mathrm{Al}_{2} \mathrm{O}_{3}$. It was stable in all studied initial toluene concentrations, discharge power while $\mathrm{C}_{7} \mathrm{H}_{8}$ conversion rate remained high - up to $82 \%$. During the process, nickel catalysts were deactivated by sooth formation on the surface. On catalysts surface, toluene decomposition products were identified including benzyl alcohol and 3-hexen-2-one.

Keywords: gliding discharge, plasma-catalytic system, tar decomposition, nickel catalyst.

\section{INTRODUCTION}

Obtaining energy from solid biomass is one of the ways of reducing fossil fuels usage ${ }^{1}$. Gasification of biomass converts it into $\mathrm{CO}, \mathrm{CO}_{2}, \mathrm{H}_{2}$ and $\mathrm{CH}_{4}$, which can be used as fuel for engines, turbines or as an ingredient for chemical synthesis ${ }^{2-6}$. One of the most significant problems during gasification of biomass is tar formation, which concentration may reach up to $100 \mathrm{~g} / \mathrm{Nm}^{3}$. It is mostly containing mono and polycyclic hydrocarbons ${ }^{7,8}$. Tars presence in the gas, may result in plugging and damaging the equipment, so it has to be cleaned before it can be used in turbines (tar limit $\left.5 \mathrm{mg} / \mathrm{Nm}^{3}\right)$ or engines $\left(50-100 \mathrm{mg} / \mathrm{Nm}^{3}\right)^{9}, \mathbf{1 0}$. Various purifying techniques are being used, including physical, non-catalytical and catalytical methods. Compared to the other methods, use of catalysts decreases temperatures required for tar elimination and increases selectivity. The most widely studied catalysts are nickel based due to the high activity and lower costs compared to noble metals $(\mathrm{Pd}, \mathrm{Pt})$. However, they can be easily deactivated due to coke formation on the surface ${ }^{11-13}$.

Plasma has been proven to be a promising solution for hydrocarbons reforming (i.e. toluene, naphthalene) but lacks catalyst's selectivity. Combining plasma and catalysts in hybrid system for tars removal results in higher conversion rate and selectivity to syngas than using those methods separately ${ }^{14-18}$.

In previous studies, commercial catalysts were used in plasma-catalytic system. High toluene conversion was obtained (up to 99\%) but large amount of soot was formed on catalysts surface ${ }^{19,20}$. Amount of coke formed during tar cracking process increases with active phase concentration ${ }^{21}$. Lowering nickel concentration on catalyst bed may lead to lower soot formation and result in higher activity. For previously studied reduced nickel catalyst RANG-19PR ${ }^{19}$, once the discharge power was completely shut off, toluene conversion dropped significantly, therefore toluene decomposition reaction might be depending on both temperature and discharge power. The purpose of this work was to identify the most suitable active phase concentration for toluene decomposition as tar model compound. Effect of initial $\mathrm{C}_{7} \mathrm{H}_{8}$ and hydrogen concentration, discharge power, catalysts surface area on unit energy consumption, calorific value and toluene conversion were studied.

\section{EXPERIMENTAL}

Two gas compositions were used during these studies (series A and B), total inlet volumetric gas flow coefficient was $1000 \mathrm{Nl} / \mathrm{h}$. $\mathrm{CO}$ and $\mathrm{CO}_{2}$ amounts were constant in each series (Table 1). Gliding discharge power in plasma-catalytic system was in range of 1500-2000 W. Toluene concentration in inlet gas was 2000, 3000 and $4500 \mathrm{ppm}$. Gliding discharge reactor was described in the previous work $^{19}$. The catalyst bed was located above the end of the electrodes where the plasma discharge ended.

Table 1. Inlet gas composition

\begin{tabular}{|c|c|c|c|c|}
\hline Composition & $\mathrm{H}_{2}$ & $\mathrm{~N}_{2}$ & $\mathrm{CO}$ & $\mathrm{CO}_{2}$ \\
\hline $\mathrm{A}$ & 0.28 & 0.47 & 0.12 & 0.13 \\
\hline $\mathrm{B}$ & 0.38 & 0.38 & 0.12 & 0.12 \\
\hline
\end{tabular}

The research was conducted using 1500, 1750 and 2000 $\mathrm{W}$ of discharge power. Power range of the reactor was limited due to plasma discharge being unstable below $1500 \mathrm{~W}$ and $2000 \mathrm{~W}$ being its highest achievable value. After the process conditions stabilized, samples were taken. During the studies, temperature of the gases increased with the increase of discharge power. To investigate temperature influence on toluene conversion and gas composition, additional samples were taken for low power and high temperature. Catalyst activity in time was also studied. Toluene conversion was calculated using below equation ${ }^{20}$ :

$$
\begin{aligned}
& x=\frac{c_{o}-c}{c_{o}} \\
& x-\text { toluene conversion, } \\
& c_{o}-\text { inlet toluene concentration, } \\
& c-\text { outlet toluene concentration. }
\end{aligned}
$$

To identify the composition of process products adsorbed on catalyst bed, its surface was risen with the acetone. Obtained samples were analyzed on mass spectrometer Thermo-Scientific ISQ. Gas composition both before and after the process was analyzed on gas chromatograph - Agilent $6890 \mathrm{~N}$ with TCD and FID detectors on ShinCarbon column. Catalysts' specific surface area was determined using a BET absorption isotherm. ASAP2020 (Micromeritics) apparatus was used for nitrogen physisorption measurements. Calorific 
values were calculated to evaluate outlet gas utility as a fuel for engines using below relations ${ }^{\mathbf{2 0}}$ :

$$
\begin{aligned}
& W=\frac{Q_{p H_{2}} \cdot a_{H_{2}}+Q_{p C O} \cdot a_{C O}+Q_{p C H_{4}} \cdot a_{C H_{4}}+Q_{p C_{2} H_{2}} \cdot a_{C_{2} H_{2}}+Q_{p C_{2} H_{4}} \cdot a_{C_{2} H_{4}}+Q_{p C_{2} H_{6}} \cdot a_{C_{2} H_{6}}}{1000} \\
& W-\text { calorific value, } \mathrm{MJ} / \mathrm{m}^{3}, \\
& Q_{p}-\text { heat of combustion, } \mathrm{kJ} / \mathrm{m}^{3}, \\
& a-\text { molar fraction of } \mathrm{CO}, \mathrm{CH}_{4}, \mathrm{C}_{2} \mathrm{H}_{2}, \mathrm{C}_{2} \mathrm{H}_{4} \text { and } \mathrm{C}_{2} \mathrm{H}_{6} .
\end{aligned}
$$

To choose the most efficient system and active phase concentration, unit energy consumption was also calculated using below equation ${ }^{22}$ :

$$
\begin{aligned}
& U E C=\frac{P}{x \cdot W_{o}\left[C_{7} H_{8}\right]} \\
& U E C=\text { unit energy consumption, } \mathrm{MJ} / \mathrm{mol}, \\
& P-\text { discharge power, W, } \\
& W_{o}\left[C_{7} H_{8}\right]-\text { toluene flow, } \mathrm{mol} / \mathrm{s}, \\
& x-\text { toluene conversion. }
\end{aligned}
$$

\section{Catalysts preparation}

Catalyst $\mathrm{NiO} / \mathrm{Al}_{2} \mathrm{O}_{3}$ and $\mathrm{Ni} / \mathrm{Al}_{2} \mathrm{O}_{3}$ containing $5 \%$, $10 \%$ and $15 \%$ by nickel weight on commercial catalysts bed G-117 (produced by INS Pulawy, Poland) had specific surface area below $15 \mathrm{~m}^{2} / \mathrm{g}$. Nickel and nickel oxide catalysts on Peshiney bed $\left(\gamma-\mathrm{Al}_{2} \mathrm{O}_{3}\right)$ had surface $200 \mathrm{~m}^{2} / \mathrm{g}$ (Table 2). As a precursor of active phase, $\left(\mathrm{NO}_{3}\right)_{2} \cdot 6 \mathrm{H}_{2} \mathrm{O}$ was used. It was placed on catalyst bed by impregnation method and dried at $90^{\circ} \mathrm{C}$ for 3 hours, then it was calcinated at $500^{\circ} \mathrm{C}$ for 5 hours. To obtain metallic active phase, nickel oxide was reduced under hydrogen volumetric flow coefficient equal to $14 \mathrm{Nl} / \mathrm{h}$, at $400^{\circ} \mathrm{C}$ for 14 hours.

Table 2. Specific surface area before and after process

\begin{tabular}{|l|c|c|}
\hline \multicolumn{3}{|c|}{$\mathrm{S}_{\mathrm{BET}}\left[\mathrm{m}^{2} / \mathrm{g}\right]$} \\
\hline \multicolumn{1}{|c|}{ Catalyst } & Before & After \\
\hline $5 \% \mathrm{Ni} / \mathrm{Al}_{2} \mathrm{O}_{3}$ & 4.8 & 4.1 \\
\hline $5 \% \mathrm{NiO} / \mathrm{Al}_{2} \mathrm{O}_{3}$ & 6.2 & 9.7 \\
\hline $10 \% \mathrm{Ni} / \mathrm{Al}_{2} \mathrm{O}_{3}$ & 8.5 & 7.7 \\
\hline $10 \% \mathrm{NiO} / \mathrm{Al}_{2} \mathrm{O}_{3}$ & 8.6 & 8.0 \\
\hline $15 \% \mathrm{Ni} / \mathrm{Al}_{2} \mathrm{O}_{3}$ & 8.8 & 13.9 \\
\hline $15 \% \mathrm{NiO} / \mathrm{Al}_{2} \mathrm{O}_{3}$ & 5.7 & 10.8 \\
\hline $10 \% \mathrm{Ni} / \mathrm{Peshiney}$ & 201.4 & 197.3 \\
\hline $10 \% \mathrm{NiO} /$ Peshiney & 208.5 & 223.2 \\
\hline
\end{tabular}

\section{RESULTS AND DISCUSSION}

The measurements of toluene decomposition were performed in plasma-catalytic systems with the use of nickel catalysts. Inlet gas composition was similar to that obtained after biomass gasification and contained hydrogen, carbon monoxide and carbon dioxide. Nitrogen was added to increase volumetric gas flow to $1000 \mathrm{Nl} / \mathrm{h}$.

Unit energy consumption (UEC) depended highly on concentration of $\mathrm{C}_{7} \mathrm{H}_{8}$. The lowest UEC was obtained while using $4500 \mathrm{ppm}$ toluene concentration for each studied system. Nickel form and its concentration on catalyst surface did not have a significant influence on UEC. Calorific value did not vary more than $10 \%$ from the initial value in most studied systems.

High toluene conversion, up to $80 \%$, was obtained for systems using $5 \%$ to $15 \%$ by weight of nickel active phase (Fig. 1). Ni as active phase was more active than $\mathrm{NiO}$. Comparison of fresh and used (after all studied series) $15 \% \mathrm{Ni} / \mathrm{Al}_{2} \mathrm{O}_{3}$ catalyst, showed decreased activity of toluene decomposition and methanation reactions (Fig. 2).
Discharge power, nickel form and toluene concentration influence were not observed when using $10 \% \mathrm{Ni}$ and $\mathrm{NiO}$ catalysts, which were nearly equally active in the most studied discharge power and initial toluene concentration. The highest conversion of toluene (82\%) was obtained while using 4500 ppm of $\mathrm{C}_{7} \mathrm{H}_{8}$ concentration. Toluene conversion dependency on initial concentration was not visible for $5 \%$ and $10 \%$ catalysts, as the radicals termination reactions were dominating over radicals reactions with toluene ${ }^{23}$. Only at $15 \%$ dependency on toluene initial concentration occurs.

The difference in toluene conversion rate for active phase concentration between $10 \%$ and $15 \%$ was significant, while between $5 \%$ and $10 \%$ was smaller. However, it was decided that $10 \% \mathrm{Ni}$ concentration is the most beneficial as conversion rates were stable in different discharge power and initial toluene concentrations. The uncertainty of toluene conversion was estimated at $5 \%$ and it was related to the measurement error.

The influence of higher concentration of hydrogen in inlet gas was studied (series B). For the most systems, higher conversions were obtained while using the gas with lower concentration of $\mathrm{H}_{2}$ (series A) (Fig. 3). Low conversion rate for series A while using 3000 ppm toluene concentration and $\mathrm{NiO}$ as active phase might be the result of taking the sample before the system was stabilized. Methanation reaction was catalyzed in all studied systems, similar to previously studied nickel catalysts $^{19,20}$. Initial hydrogen and toluene concentration had a slight impact on the amount of methane formed during the process, it did not exceed $50 \mathrm{ppm}$. Molar fractions of inlet gas components did not change by more than $10 \%$ percent and remained stable during the process for both studied series (Fig. 4). Slight decrease in hydrogen concentration might be caused by methane formation and reactions with oxygen radical that could be formed by $\mathrm{CO}_{2}$ dissociation ${ }^{\mathbf{1 9}}$. Trace amount of oxygen was also detected in outlet gas.

In previously studied systems with the use of nickel catalyst (RANG-19PR, G-117) $)^{\mathbf{1 9}, 20,24}$ toluene decomposition was rising with both temperature and discharge power. To check the influence of each of those separately, by the end of experiments when the temperature was the highest $\left(250-300^{\circ} \mathrm{C}\right)$, power was lowered to $1500 \mathrm{~W}$. For both, reduced and oxidized nickel catalysts in past studies, conversion of toluene was higher while using high temperature at low power $1500 \mathrm{~W}$. The next step with the use of RANG-19PR catalyst was to completely shut of the discharge power. It resulted in rapid decrease in toluene conversion rate ${ }^{19}$. Those steps have shown, that the studied process is not only catalytical or thermal decomposition but the plasma discharge is also important.

Dependence similar to previous studies was observed while using $5 \%$ and $10 \%$ active phase concentration (Fig. 5a). Conversion increased with both power and temperature. When power was reduced to $1500 \mathrm{~W}$, the conversion was the highest due to higher temperature by $50^{\circ} \mathrm{C}$ than using $2000 \mathrm{~W}$. While using $10 \% \mathrm{Ni} / \mathrm{Al}_{2} \mathrm{O}_{3}$ catalyst, conversion of toluene was constant with an increase of power and temperature (Fig. 5b). The high temperature generated in gliding discharge increased the reaction rate and produced radicals, which reacted with toluene and its intermediate products. 

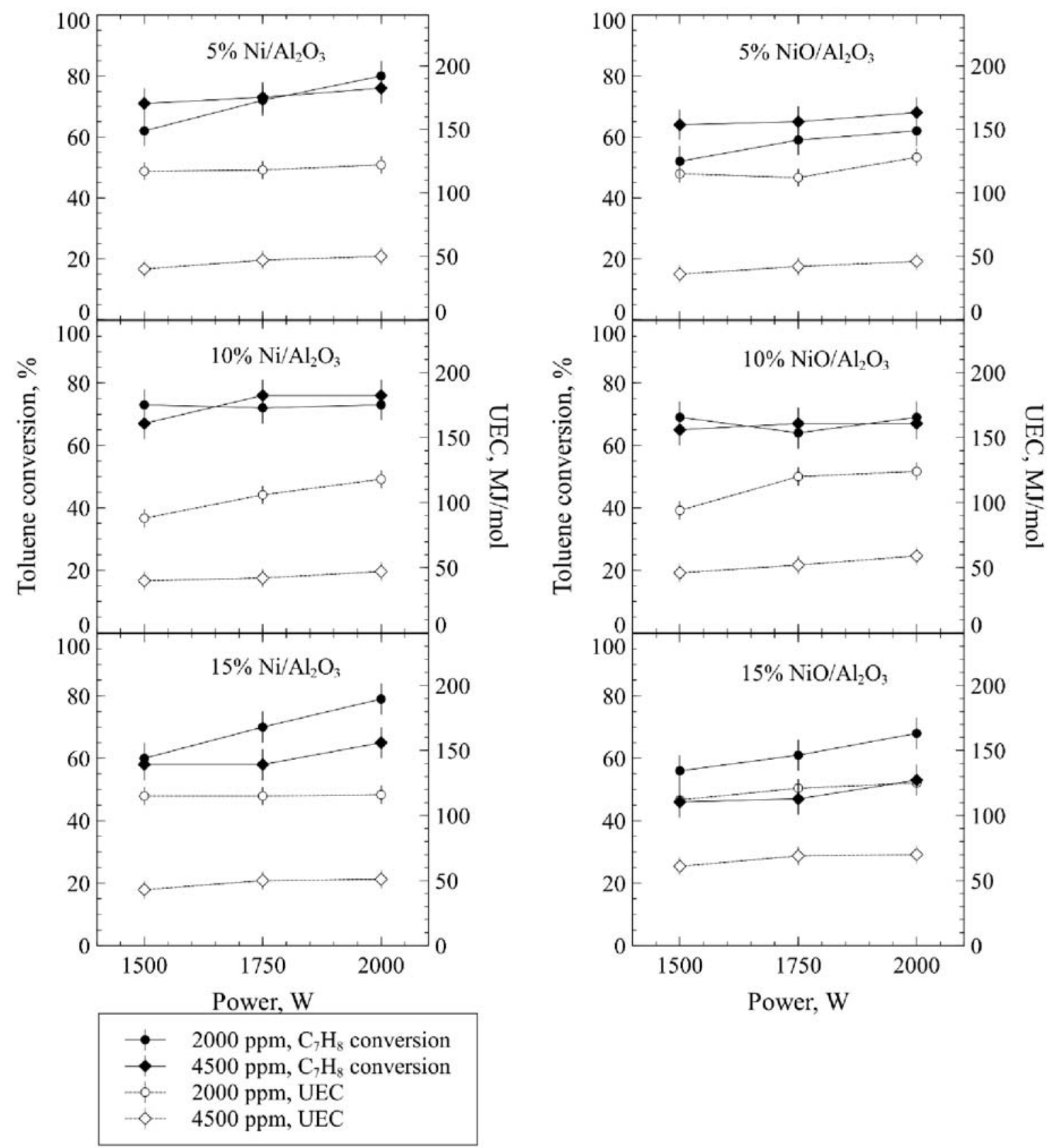

Figure 1. Toluene conversion and unit energy consumption from power for $\mathrm{NiO} / \mathrm{Al}_{2} \mathrm{O}_{3}$ and $\mathrm{Ni} / \mathrm{Al}_{2} \mathrm{O}_{3}$ catalysts containing $5 \%, 10 \%$ and $15 \%$ active phase. Initial toluene concentration 2000 and $4500 \mathrm{ppm}$, series A

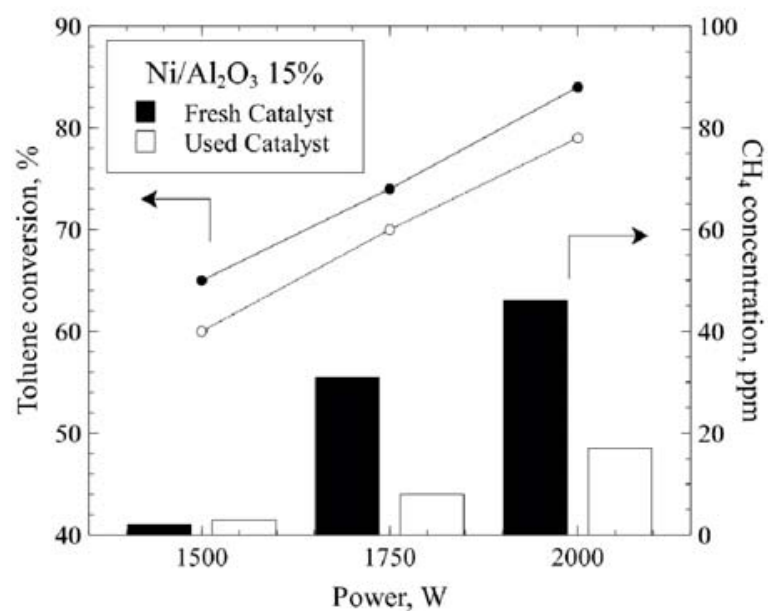

Figure 2. Toluene conversion and methane concentration for fresh and used (after all studied series) $15 \% \mathrm{Ni} / \mathrm{Al}_{2} \mathrm{O}_{3}$ catalyst versus power. Initial toluene concentration 2000 ppm, series A
Samples were taken using the same discharge power after the conditions have stabilized. In the systems with $15 \% \mathrm{NiO} / \mathrm{Al}_{2} \mathrm{O}_{3}$ and $\mathrm{Ni} / \mathrm{Al}_{2} \mathrm{O}_{3}$ catalysts, higher amounts of methane were produced. It resulted in reaching higher temperatures during the process than while using the catalyst with lower active phase concentration.

The influence of the specific surface area of the catalyst bed was also studied in this work. Two catalysts with very different surface areas were compared. The specific area of $\alpha-\mathrm{Al}_{2} \mathrm{O}_{3}$ was not exceeding $10 \mathrm{~m}^{2} / \mathrm{g}$ while Peshiney's $\left(\gamma-\mathrm{Al}_{2} \mathrm{O}_{3}\right)$ area was over $200 \mathrm{~m}^{2} / \mathrm{g}$. Surface areas were comparable both before and after the process, the difference might be coming from carbon deposits that formed during the process on the catalyst surface. Catalysts on Peshiney absorbed toluene below its boiling point, therefore samples were not taken while using low power and temperatures below $110^{\circ} \mathrm{C}$. Toluene conversions were lower than those obtained during this study for catalysts with a small surface area - up to $60 \%$ for $\mathrm{NiO} /$ Peshiney 

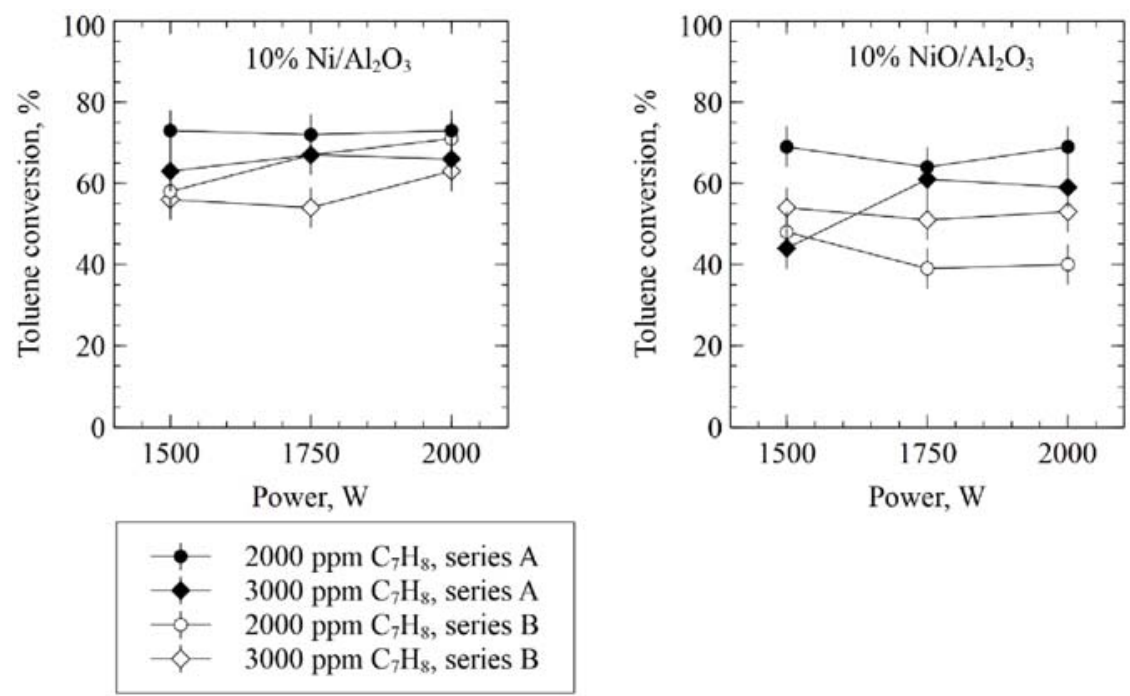

Figure 3. Effect of discharge power and initial hydrogen concentration on toluene conversion for $10 \% \mathrm{NiO} / \mathrm{Al}_{2} \mathrm{O}_{3}$ and $10 \%$ $\mathrm{Ni} / \mathrm{Al}_{2} \mathrm{O}_{3}$ catalysts. Initial toluene concentration 2000 and $3000 \mathrm{ppm}$

A

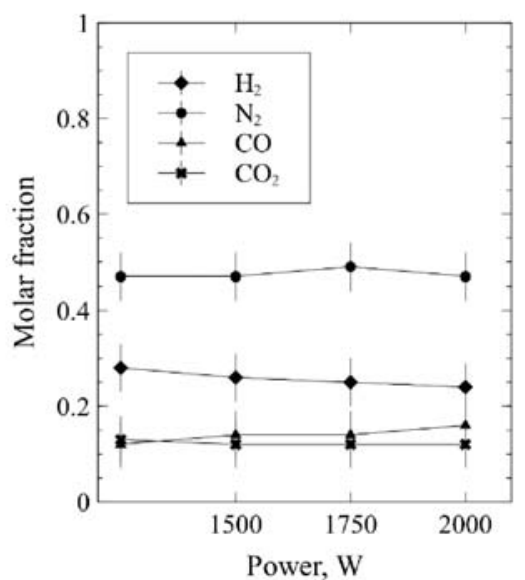

B

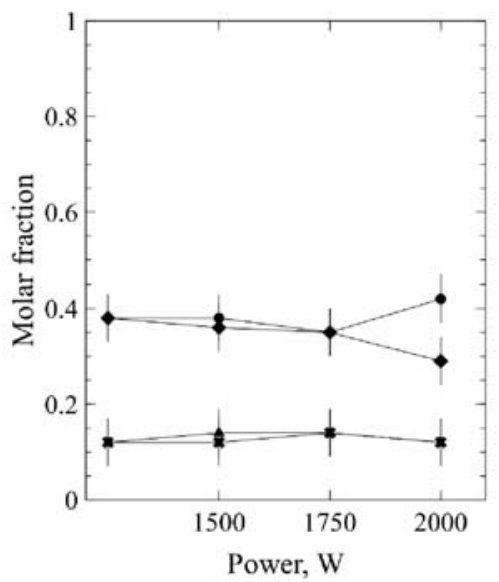

Figure 4. Effect of discharge power on gas composition for $10 \% \mathrm{Ni} / \mathrm{Al}_{2} \mathrm{O}_{3}$ catalyst. Initial toluene concentration 2000ppm, series $\mathrm{A}$ and $\mathrm{B}$
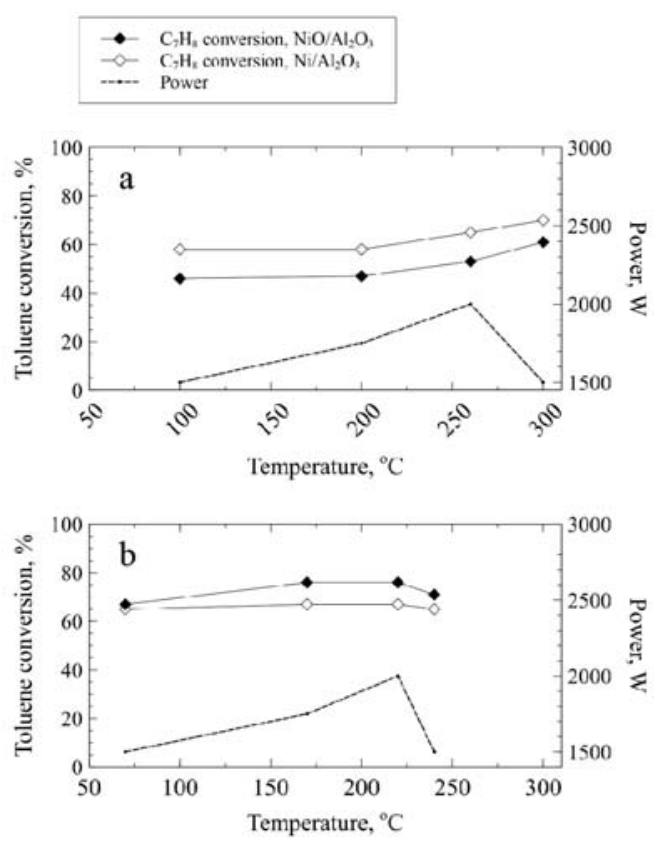

Figure 5. Effect of temperature and discharge power on toluene conversion for $15 \%$ (a) and $10 \%$ (b) of $\mathrm{NiO} / \mathrm{Al}_{2} \mathrm{O}_{3}$ and $\mathrm{Ni} / \mathrm{Al}_{2} \mathrm{O}_{3}$ catalysts. Initial toluene concentration $4500 \mathrm{ppm}$, series A and $80 \%$ for $\mathrm{Ni} /$ Peshiney. Unit energy consumption was higher than in other studied in this work systems due to lower conversion, which was another disadvantage of using catalysts on Peshiney bed.

One of the problems during previous studies was mechanical damages of catalyst and carbon deposits formed on its surface, which led to catalysts deactivation. What is more, intermediate products of toluene decomposition could also be adsorbed on the surface of the catalyst. It resulted in blocking of the active sites on the surface and lowered its activity. Toluene decomposition products were identified by mass spectrometry. In outlet gas benzyl alcohol, 3-hexen-2-one, methanol and trace amount of $\mathrm{C} 2$ were present as products of toluene decomposition. A possible reaction mechanism was proposed for identified products (Fig. 6). Water, which was a product of carbon monoxides methanation was important source of excited $\mathrm{HO}^{\bullet}$ radical. The first step of the decomposition process was $\mathrm{H}$ atom removal from methyl group. This $\mathrm{C}-\mathrm{H}$ bond had the lowest energy in toluene particle so it was the most vulnerable for high energetic radicals influence. Reactive methyl radical was formed and might be oxidized to benzoic alcohol, aldehyde and acid. Further steps might lead to creation of benzene radical and phenol. High energy radicals 
were able to break toluene ring to form stable particles like 3-hexen-2-one identified in this work. Radicals and electrons were able to initialize further reactions that could lead to formation of simple particles like $\mathrm{CO}$, $\mathrm{CO}_{2}$, hydrogen and water. Identified methanol might be formed in catalytic methane oxidation ${ }^{25-28}$.

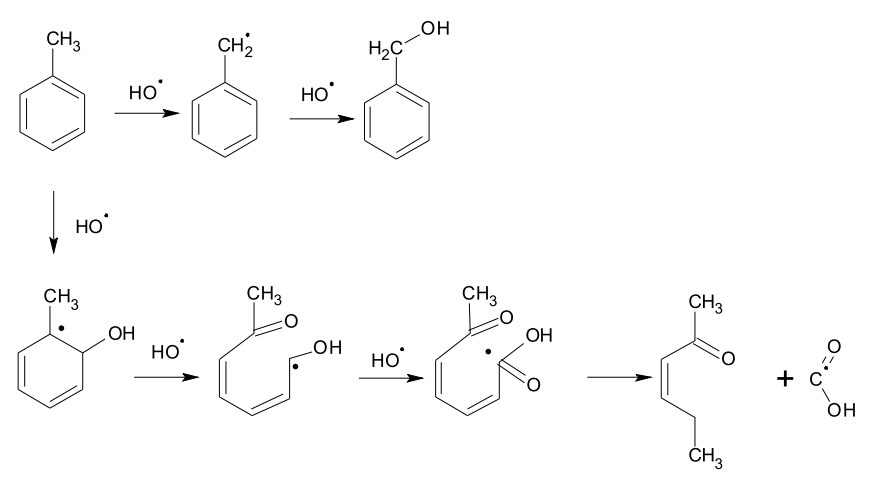

Figure 6. Possible reaction mechanism of toluene decomposition

\section{CONCLUSIONS}

Toluene decomposition as a tar model was possible in coupled plasma-catalytic system using nickel catalysts in $\mathrm{NiO}$ and $\mathrm{Ni}$ forms. The optimal concentration of the active phase was identified to be $10 \%$ of nickel by weight on $\mathrm{Al}_{2} \mathrm{O}_{3}$ catalyst bed. Obtained high conversion - up to $82 \%$ was stable in all studied toluene concentrations and used power. Nickel catalysts were deactivated during the process due to soot formation. Initial gas similar in composition to the gas after biomass gasification was beneficial for tar elimination, additional hydrogen was not enhancing toluene decomposition process. Calorific value was stable in most systems.

\section{LITERATURE CITED}

1. Wang, Z., Bui, Q., Zhang, B. \& Pham, T.L.H. (2020). Biomass energy production and its impacts on the ecological footprint: An investigation of the G7 countries. Sci. Total Environ. 743, 140741. DOI: 10.1016/j.scitotenv.2020.140741.

2. Shahabuddin, M., Alam, M.T., Krishna, B.B., Bhaskar, T. \& Perkins, G. (2020). A review on the production of renewable aviation fuels from the gasification of biomass and residual wastes. Biores. Technol. 312, 123596. DOI: 10.1016/j. biortech.2020.123596.

3. Xiang, Y., Cai, L., Guan, Y., Liu, W., Cheng, Z. \& Liu, Z. (2020). Study on the effect of gasification agents on the integrated system of biomass gasification combined cycle and oxy-fuel combustion. Energy. 206, 118131. DOI: 10.1016/j. energy.2020.118131.

4. Marculescu, C., Cenuşă, V. \& Alexe, F. (2016). Analysis of biomass and waste gasification lean syngases combustion for power generation using spark ignition engines. Waste Manage. 47(A), 133-140. DOI: 10.1016/j.wasman.2015.06.043.

5. Hernández, J.J., Lapuerta, M. \& Barba, J. (2015). Effect of partial replacement of diesel or biodiesel with gas from biomass gasification in a diesel engine. Energy. 89, 148-157. DOI: 10.1016/j.energy.2015.07.050.

6. Caliandro, P., Tock, L., Ensinas, A.V. \& Marechal, F. (2014). Thermo-economic optimization of a Solid Oxide Fuel Cell - Gas turbine system fuelled with gasified lignocellulosic biomass. Energy Convers. Manag. 85, 764-773. DOI: 10.1016/j. enconman.2014.02.009.

7. Di Carlo, A., Borello, D., Sisinni, M., Savuto, E., Venturini, P., Bocci, E. \& Kuramoto, K. (2015). Reforming of tar contained in a raw fuel gas from biomass gasification using nickel-mayenite catalyst. Int. J. Hydrog. Energy. 40(30), 9088-9095. DOI: 10.1016/j.ijhydene.2015.05.128.

8. Kinoshita, C.M., Wang, Y. \& Zhou, J. (1994). Tar formation under different biomass gasification conditions. J. Anal. Appl. Pyrolysis, 29(2), 169-181. DOI: 10.1016/0165-2370(94)00796-9.

9. Thapa, S., Bho, P.R., Kumar, A. \& Huhnke, R.L. (2017). Effects of Syngas Cooling and Biomass Filter Medium on Tar Removal. Energies. 10(3), 349. DOI: 10.3390/en10030349.

10. Asadullah, M. (2014). Biomass gasification gas cleaning for downstream applications: A comparative critical review, Renew. Sust. Energ. Rev. 40, 118-132. DOI: 10.1016/j.rser.2014.07.132.

11. Shen, Y. \& Yoshikawa, K. (2013). Recent progresses in catalytic tar elimination during biomass gasification or pyrolysis-A review. Renew. Sust. Energ. Rev. 21, 371-392. DOI: 10.1016/j.rser.2012.12.062.

12. Yu, H., Liu, Y., Liu, J. \& Chen, D. (2019). High catalytic performance of an innovative $\mathrm{Ni} /$ magnesium slag catalyst for the syngas production and tar removal from biomass pyrolysis. Fuel. 254, 115622. DOI: 10.1016/j.fuel.2019.115622.

13. Laprune, D., Farrusseng, D., Schuurman, Y., Meunier, F.C., Pieterse, J.A.Z., Steele, A.M. \& Thorpe, S. (2018). Effects of $\mathrm{H}_{2} \mathrm{~S}$ and phenanthrene on the a-ctivity of $\mathrm{Ni}$ and Rh-based catalysts for the reforming of a simulated biomass-derived producer gas. Appl. Catal. B. 221, 206-214. DOI: 10.1016/j. apcatb.2017.09.015.

14. Liu, Y., Song, J., Diao, X., Liu, L. \& Sun, Y. (2020). Removal of tar derived from biomass gasification via synergy of non-thermal plasma and catalysis. Sci. Total Environ. 721, 137671. DOI: 10.1016/j.scitotenv.2020.137671.

15. Wanga, Y., Yangb, H. \& Tu, X. (2019). Plasma reforming of naphthalene as a tar model compound of biomass gasification. Energy Convers. Manag. 187, 593-604. DOI: 10.1016/j. enconman.2019.02.075.

16. Liu, L., Liu, Y., Song, J., Ahmad, S., Liang, J. \& Sun, Y. (2019). Plasma-enhanced steam reforming of different model tar compounds over Ni-based fusion catalysts. J. Hazard. Mater. 377, 24-33. DOI: 10.1016/j.jhazmat.2019.05.019.

17. Tao, K., Ohta, N., Liu, G., Yoneyama, Y., Wang, T. \& Tsubaki, N. (2013). Plasma enhanced catalytic reforming of biomass tar model compound to syngas. Fuel. 104, 53-57. DOI: 10.1016/j.fuel.2010.05.044.

18. Liu, L., Wang, Q., Ahmad, S., Yang, X., Ji, M. \& Sun, Y. (2018). Steam reforming of toluene as model biomass tar to $\mathrm{H}_{2}$-rich syngas in a DBD plasma-catalytic system. J. Energy Inst. 91(6), 927-939. DOI: 10.1016/j.joei.2017.09.003.

19. Młotek, M., Woroszył, J., Ulejczyk, B. \& Krawczyk, K. (2019). Coupled Plasma-Catalytic System with Rang 19PR Catalyst for Conversion of Tar. Sci. Rep. 9, 13562. DOI: 10.1038/ s41598-019-49959-4.

20. Młotek, M., Ulejczyk, B., Woroszył, J. \& Krawczyk, K. (2020). Decomposition of Toluene in Coupled Plasma-Catalytic System. Ind. Eng. Chem. Res. 59(10), 4239-4244. DOI: 10.1021/ acs.iecr.9b04330.

21. Lu, P., Huang, Q., Bourtsalas, A.C., Chi1, Y. \& Yan, J. (2019). Effect of Operating Conditions on the Coke Formation and Nickel Catalyst Performance During Cracking of Tar. Waste Biomass Valorization. 10, 155-165. DOI: 10.1007/ s12649-017-0044-5.

22. Młotek, M., Reda, E. \& Krawczyk, K. (2015). Conversion of tetrachloromethane in large scale gliding discharge reactor. Open Chem. 13, 212-217. DOI: 10.1515/chem-2015-0022.

23. Yan, K. \& Van Heesch, E.J.M. (2001). From Chemical Kinetics to Streamer Corona Reactor and Voltage Pulse Generator. Plasma Chem. Plasma Process. 21(1), 107-137. DOI: 10.1023/A:1007045529652.

24. Młotek, M., Ulejczyk, B., Woroszył, J., Walerczak, I. \& Krawczyk, K. (2017). Purification of the gas after pyrolysis in coupled plasma-catalytic system. Pol. J. Chem. Technol. 19(4), 94-98. DOI: 10.1515/pjct-2017-0073. 
25. Nunez, C.M., Ramsey, G.H., Ponder, W.H., Abbott, J.H., Hamel, L.E. \& Kariher, P.H. (1993). Corona Destruction: An Innovative Control Technology for VOCs and Air Toxics. J. Air Waste Manag. Assoc. 43(2), 242-247. DOI: 10.1080/1073161X.1993.10467131.

26. Xua, W., Jianga, X., Chena, H., Chena, X., Chenb, L., Wub, J., Fub, M. \& Yeb, D. (2020). Adsorption-discharge plasma system for toluene decomposition over Ni-SBA catalyst: In situ observation and humidity influence study. Chem. Eng. 382, 122950. DOI: 10.1016/j.cej.2019.122950.
27. Du, C.M., Yan, J.H. \& Cheron, B. (2007). Decomposition of toluene in a gliding arc discharge plasma reactor. Plasma Sources Sci. Technol. 16, 791-797. DOI: 10.1088/0963$0252 / 16 / 4 / 014$.

28. Lee, H. \& Kim, D.H. (2018). Direct methanol synthesis from methane in a plasma-catalyst hybrid system at low temperature using metal oxide-coated glass beads. Sci. Rep. 8, 9956. DOI: 10.1038/s41598-018-28170-x. 